Other SHEA members who gave major presentations or served as moderators were Drs. R. Aber, G. Counts, D. Craven, L. Donowitz, R. Garibaldi, D. Henderson, L. Herwaldt, W. Hierholzer, W. Martone, J. McGowan, S. Ponce de Leon, W. Rutala, W. Schaffner, R. Sherertz, T. Townsend and $\mathrm{R}$. Weinstein.

Representatives of 19 countries (Argentina, Bermuda, Brazil, Canada, Colombia, Costa Rica, Cuba, Chile, Ecuador, Guatemala, Jamaica, Mexico, Panama, Peru, Puerto Rico, Turks and Caicos, United States, Uruguay and Venezuela) attended.

This conference resulted in 17 main recommendations to $\mathrm{PAHO} /$ World Health Organization (WHO) and member countries. The thrust of these recommendations was to establish/improve education, exchange of information, formal meetings and research on infection control at hospital, local, regional, national and international levels; to mandate active infection control and antibiotic review and control activities at each of these levels; to develop a system of reference laboratories to facilitate microbiologic diagnostics and to standardize antibiotic susceptibility testing; and to request the assistance of PAHO/ WHO in carrying out these goals and in establishing a society for the prevention and control of hospital infections in Latin America and the Caribbean.

\section{SHEA/CDC Hospital Epidemiology Course}

Work day and night for an extended weekend in Coconut Grove, Florida and love it? That's what the 55 attendees and more than 12 instructors at the March 29 through April 1, 1990 SHEA/
CDC Training Program did. The course, intended primarily for infectious disease (ID) fellows, also attracted a sizable contingent of young ID faculty. Seven of the fellows attended on educational fellowships sponsored by Merck, Sharp and Dohme.

The lectures, including presentations on epidemiology and transmission of nosocomial pathogens, surveillance systems, quality assurance, personnel health and disinfection and waste management, were supplemented by three outbreak investigation working group sessions, practical how-to presentations on the role of the infection control practitioner and a session on "getting started." A new feature of the course was an intensive introduction to basic epidemiologic concepts prepared by Dr. J. Freeman with the assistance of Drs. J. McGowan and D.H. Culver. Miami weather, coffee breaks by the pool and a group dinner sponsored by Merck, Sharp and Dohme rounded out the program.

The course was hosted by Dr. N.J. Ehrenkranz and his colleagues from the South Florida Infection Control Consortium. The course faculty included Drs. G.W. Counts, D.H. Culver, Ehrenkranz, M.S. Favero, J. Freeman, D.A. Goldmann, W.J. Hierholzer, Jr., W.R. Jarvis, R.L. Marier, W.J. Mar-tone, J.E. McGowan, O.C. Tablan and Ms. P. DeStefano, E. Mazzei and M. Wiener.

\section{Position Paper: Waste Management}

A task force chaired by Dr. F. Rhame is preparing a SHEA position paper on waste management. SHEA members who wish to provide their insights should contact
Drs. Rhame (612-626-5306), C.G. Mayhall (901-528-5770) or W. Rutala (919-966-1636).

\section{SHEA Symposium at Montreal International Congress for Infectious Disease}

SHEA has been invited to present a symposium on infection control in developing countries at the upcoming international congress for infectious diseases, July 15-19, 1990 in Montreal. Participants will include Drs. E. O'Rourke, D. Goldmann and F. Otaiza (Chile) from SHEA, as well as E. Tikhomirov (World Health Organization), W. Kadzia (Poland) and S. Danchivijitr (Thailand).

\section{Pertussis}

We recently have seen at least two nosocomial cases of pertussis and have become aware of an increased incidence of reported cases. Because timely erythromycin treatment of patients with clinical pertussis and of selected contacts may decrease infectivity and limit secondary spread of infection, pertussis should be considered as a possible diagnosis in patients and hospital personnel with prolonged cough, especially if there are paroxysms, whoops or post-tussive vomiting. In fact, because of variable sensitivity and specificity of culture or DFA testing for Bordetella pertussis, the Centers for Disease Control has recommended using a clinical case definition for pertussis. The recommended definition, a cough illness lasting for 14 or more days, had $91 \%$ sensitivity and $90 \%$ specificity compared to pertussis serology in one study. 